\title{
Leukotrienes: Biosynthesis, Metabolism, and Pathophysiologic Significance
}

\author{
ERTAN MAYATEPEK AND GEORG F. HOFFMANN \\ Department of General Pediatrics, University Children's Hospital, Heidelberg, Germany
}

Leukotrienes (LT) comprise a group of biologically highly potent lipid mediators synthesized by 5-lipoxygenase from 20-carbon polyunsaturated fatty acids, predominantly arachidonate (1-3). They include the cysteinyl LT, $\mathrm{LTC}_{4}, \mathrm{LTD}_{4}$, $\mathrm{LTE}_{4}$, representing biologically active constituents of the longknown "slow-reacting substance of anaphylaxis" and the dihydroxyeicosatetraenoate, $\mathrm{LTB}_{4}$. LT act at nanomolar concentrations in intercellular communication, signal transduction and on host defense. Extensive studies during the last years have demonstrated that LT are not only locally acting mediators but also systemically acting substances.

Recent progress in LT research has led to a more detailed understanding of their biosynthesis, degradation, and inactivation. Moreover, the pathogenetic role of LT in various human diseases has become recognized, and inhibitors of biosynthesis as well as receptor antagonists interfering with signal transduction were developed.

The aims of the review are 1) to update the current knowledge of the synthesis, metabolism, and principal role of LT as mediators under physiologic and pathologic conditions; 2) to give a brief overview about the development, state of the art, and limitations of analytical techniques; 3) to discuss clinical conditions with particular emphasis on pediatric diseases in which LT are assumed to play a pathobiologic role; 4) to illustrate how present knowledge has influenced current pathophysiologic concepts; and 5) to briefly present future aspects of biochemical and clinical research on LT.

\section{BIOSYNTHESIS, METABOLISM, AND INACTIVATION}

$\mathrm{Ca}^{2+}$-dependent activation of 5-lipoxygenase induces conversion of arachidonate via 5-HPETE (5S-hydroperoxy-6,8, 11,14-eicosatetraenoate) to the labile 5,6-epoxide $\mathrm{LTA}_{4}$ (4) (Fig. 1).

By enzymatic action of $\mathrm{LTA}_{4}$ hydrolase, $\mathrm{LTB}_{4}(5 S, 12 R$ dihydroxy-6,8,10,14-eicosatetraenoate) is formed (5). Alternatively, enzymatic conjugation of $\mathrm{LTA}_{4}$ with glutathione at carbon 6 catalyzed by $\mathrm{LTC}_{4}$ synthase results in the formation of $\mathrm{LTC}_{4}$, the primary cysteinyl LT (6). Stepwise cleavage of glutamate and glycine from LTC $_{4}$ by $\gamma$-glutamyltransferase and dipeptidase followed by enzymatic action of $\mathrm{N}$ -

Correspondence: Dr. Ertan Mayatepek, University Children's Hospital, Im Neuenheimer Feld 150, D-69120 Heidelberg, Germany.

E.M. (Ma 1314/2-1) and G.F.H. are supported by the Deutsche Forschungsgemeinschaft. acetyltransferase yields $\mathrm{LTD}_{4}, \mathrm{LTE}_{4}$, and $\mathrm{N}$-acetyl-LTE spectively (2). $\mathrm{LTD}_{4}$ represents the biologically most potent cysteinyl LT.

LT are predominantly produced by macrophages, monocytes, neutrophils, eosinophils, mast cells, and basophils (7-9). Additionally, transcellular synthesis of $\mathrm{LTB}_{4}$ and $\mathrm{LTC}_{4}$ from the 5,6-epoxide $\mathrm{LTA}_{4}$ occurs in endothelial cells, platelets, mast cells, lymphocytes, and erythrocytes (10-13). Table 1 summarizes the biologic effects and functions of the cysteinyl $\mathrm{LT}$ and $\mathrm{LTB}_{4}$.

Enzyme-catalyzed chemical modification of the cysteinylglycine moiety of $\mathrm{LTD}_{4}$ followed by stepwise $\omega$-oxidation and $\beta$-oxidation of the degradation products of $\mathrm{LTE}_{4}$ and $\mathrm{LTB}_{4}$ result in complete inactivation (Fig. 1). $\mathrm{LTC}_{4}$ and $\mathrm{LTD}_{4}$ are rapidly metabolized in the blood circulation to $\mathrm{LTE}_{4}$ with an half-life of $30 \mathrm{~s}$ up to $4 \mathrm{~min}(14-16)$. Therefore, the estimation of the biologically active LT in plasma is without real significance.

The liver represents the main organ for the uptake, metabolic inactivation, and biliary elimination of LT and their metabolites (17-20). However, renal uptake also contributes to the disappearance of cysteinyl LT from the circulation (17, 21-23). Changes in the urinary excretion of $\mathrm{LTE}_{4}$ are assumed to reflect short-term changes in the rate of formation of $\mathrm{LTC}_{4}$ (24).

Unlike the prostaglandins that are degraded from the carbon1-carboxyl-group, $\mathrm{LTE}_{4}$ and $\mathrm{LTB}_{4}$ are further degraded from the $\omega$-end by $\beta$-oxidation of their respective $\omega$-carboxymetabolites. $\omega$-Oxidation of $\mathrm{LTB}_{4}$ to $\omega$-hydroxy-LTB $\mathrm{LT}_{4}, \omega$-aldehyde- $\mathrm{LTB}_{4}$, and $\omega$-carboxy- $\mathrm{LTB}_{4}$ has been shown to occur in leukocytes and hepatocytes (25-27). Hepatocytes were also shown to $\beta$-oxidize $\omega$-carboxy- $\mathrm{LTB}_{4}$ to $\omega$-carboxy-dinor$\mathrm{LTB}_{4}$ and $\omega$-carboxy-tetranor-LTB $\mathrm{LT}_{3}(26-28)$. Furthermore, the liver converts $\mathrm{LTE}_{4}$ to the respective $\omega$-hydroxy and $\omega$-carboxy metabolites $(29,30)$. These substances are further degraded by $\beta$-oxidation yielding $\omega$-carboxy-dinor-LTE $\mathrm{L}_{4}$ and $\omega$-carboxy-tetranor-LTE $\mathrm{LE}_{3}(31,32)$ (Fig. 1). Measurement of urinary $\omega$ - and $\beta$-oxidation products of $\mathrm{LTE}_{4}$ may reflect long-term changes in cysteinyl LT biosynthesis and metabolism (24).

Peroxisomes have been recently identified as the site of $\beta$-oxidation of the LT from the $\omega$-end (33). Whereas the cysteinyl LT $\omega$-carboxy-N-acetyl- $\mathrm{LTE}_{4}$ has been found to be exclusively $\beta$-oxidized in peroxisomes, $\omega$-carboxy-LTB $\mathrm{LT}_{4}$ was degraded both in isolated peroxisomes and mitochondria. Further evidence for the essential role of peroxisomes in the 


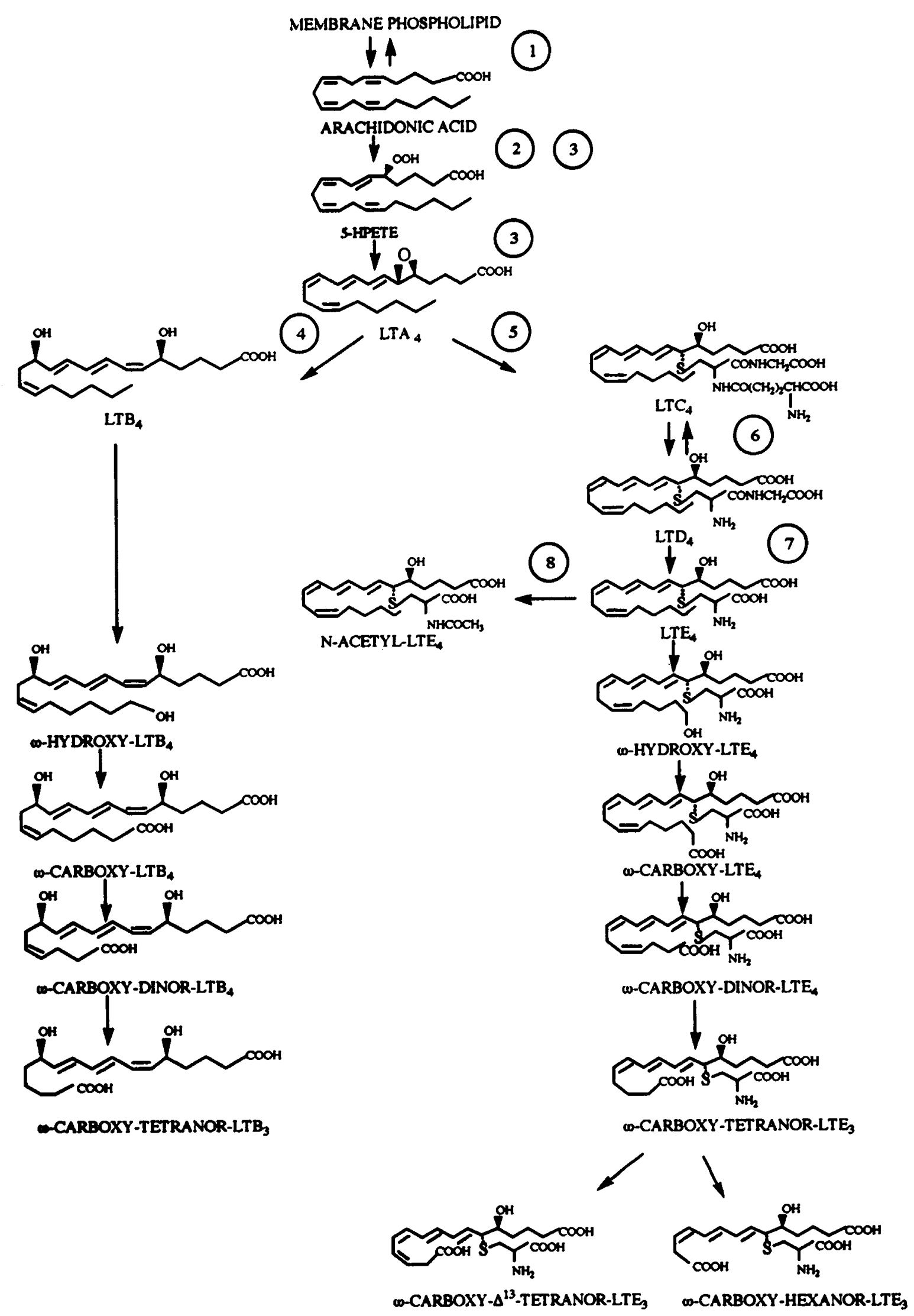

Figure 1. Metabolic pathway of LT biosynthesis and metabolism. The numbers refer to the enzymes most active in the pathways, as follows: 1 , phosholipases; 2, 5-lipoxygenase-activating protein; 3, 5-lipoxygenase; 4, LTA $_{4}$ hydrolase; 5, LTC $_{4}$ synthase; $6, \gamma$-glutamyl transpeptidase; 7 , $\gamma$-glutamyl dipeptidase; 8 , $\mathrm{N}$-acetyltransferase. 
Table 1. Biologic effects of $L T$

\begin{tabular}{ll}
\hline \multicolumn{1}{c}{ Cysteinyl LT } & \multicolumn{1}{c}{$\mathrm{LTB}_{4}$} \\
\hline $\begin{array}{l}\text { Vasoconstriction } \\
\text { Increase of vascular permeability in } \\
\text { postcapillary venules }\end{array}$ & $\begin{array}{c}\text { Aggregation; chemokinesis } \\
\text { Chemotaxis; release of lysosomal } \\
\text { enzymes; stimulation of }\end{array}$ \\
$\begin{array}{c}\text { Bronchoconstriction } \\
\text { Stimulation of mucus secretion }\end{array}$ & $\begin{array}{c}\text { Adhesion and transendothelial } \\
\text { migration of neutrophils }\end{array}$ \\
Intestinal contraction (ileum) & Increase of vascular permeability \\
Plasma extravasation & (in the presence of PGE P $_{2}$ \\
Decrease of blood pressure & Enhancement of C3b receptor \\
Reduction of myocardial contractility & expression and \\
and coronary blood flow & complement-dependent \\
Decrease of renal blood flow and & cytotoxicity \\
GFR & Modulation of lymphocyte function \\
Proliferation of glomerular & Affector of the production and \\
endothelial cells & action of cytokines \\
Release of LH-releasing hormone & Release of intracellular calcium \\
Stimulation of prostacyclin synthesis & Increase of cAMP and cGMP \\
(endothelium) & synthesis \\
\hline
\end{tabular}

catabolism of LT has been obtained by studying endogenous LT excretion in the urine of patients with peroxisome deficiency disorders (34). In these patients the defect of peroxisomal LT degradation results in increased levels of $\mathrm{LTE}_{4}$ and $\mathrm{LTB}_{4}$. In addition, the concentrations of urinary $\omega$-carboxy$\mathrm{LTE}_{4}$ and $\omega$-carboxy-LTB ${ }_{4}$, which are the immediate substrates for peroxisomal $\beta$-oxidation, are markedly increased.

\section{ANALYTICAL METHODS FOR DETERMINATION IN BIOLOGIC FLUIDS}

The low nanomolar and picomolar concentrations of these mediators in biologic fluids make analysis difficult. Additionally, LT have an extremely short half-life in vivo. LT are susceptible to oxidative degradation during sample preparation. They are easily artificially generated and released in vitro from blood leukocytes during blood sampling (22). Therefore, LT analysis in plasma is of little meaning and not a reliable way to evaluate the role of LT under pathologic conditions. The generation of LT, especially $\mathrm{LTB}_{4}$, in isolated and stimulated white blood cells can be used to obtain information about the role of LT in various disease states (7, 35-37). Activation is carried out with different stimuli such as calcium ionophore A23187, zymosan, antigen, or aggregated immunoglobulins. This approach appears to be the most reliable in vitro method to estimate $\mathrm{LTB}_{4}$ generation.

For the investigation of systemic cysteinyl LT production, species-characteristic index metabolites could be defined by tracer studies. After administration of radiolabeled $\mathrm{LTC}_{4}$ to humans, $\left[{ }^{3} \mathrm{H}\right] \mathrm{LTE}_{4}$ is the main urinary metabolite $(32,38,39)$. In contrast, $\left[{ }^{3} \mathrm{H}\right] \mathrm{LTB}_{4}$ is not detectable in urine after i.v. $\left[{ }^{3} \mathrm{H}\right] \mathrm{LTB}_{4}$ infusion (40). In addition, i.v. administration of $\left[{ }^{3} \mathrm{H}\right] \mathrm{LTE}_{4}$ leads to the detection of $\omega$-and $\beta$-oxidation products that are excreted into bile and urine $(31,32,38)$. In humans, urinary $\mathrm{LTE}_{4}$ has been proposed as an index metabolite for the systemic generation of cysteinyl LT in vivo (36, 41-44). To get reliable information on the role of cysteinyl LT in pathologic states or after pharmacologic intervention, cysteinyl LT metabolites have to be analyzed in urine.
Quantitative determinations of LT can be performed by bioassays, HPLC, RIA or enzyme immunoassays, or gas chromatography-mass spectrometry. Extraction, purification, and separation of LT metabolites by HPLC serve as an initial analytical step (45). The use of immunoassays for LT measurements requires that identification be verified by HPLC or mass spectrometry. The method of choice for unequivocal identification is gas chromatography-mass spectrometry (4648 ). Because no specific antibodies for $\omega$ - and $\beta$-oxidation products of $\mathrm{LTE}_{4}$ are available, a recently described procedure for determination of $\omega$-carboxy- $\mathrm{LTE}_{4}$ in human urine using ${ }^{18} \mathrm{O}$-labeled standards provides a promising technique (34).

\section{PATHOPHYSIOLOGIC ROLE OF LT IN HUMAN DISEASES}

In recent years, research on LT and their significance in human diseases focused on the determination of the different LT in biologic fluids and tissues. The amounts of these biologically highly active mediators were found to be sufficient to elicit pathophysiologic responses in humans and experimental animals in a variety of conditions. A selection of diseases in which increased or impaired LT synthesis or metabolism is implicated is presented in Table 2 .

Lung diseases. In acute asthma, allergic rhinitis, and aspirinsensitive and exercise-induced asthma, elevated concentrations of LT have been recovered from biologic fluids, including bronchoalveolar lavage, sputum, blood, and urine, spontaneously as well as after antigen challenge $(43,49-53)$ (Table 2). Clinical studies with LT receptor antagonists (see below) resulted in clinical improvement. Because LT are up to 1000 times more potent constrictors of bronchial smooth muscle than histamine and because of their capacity to stimulate mucus secretion, their mediator role in the pathogenesis of asthma is evident.

Sputum, lung lavage, or lung edema fluid obtained from patients with cystic fibrosis, adult respiratory distress syndrome, and neonatal hypoxemia with pulmonary hypertension contained elevated concentrations of cysteinyl LT (54-56). Recently, it was suggested that the aspiration of tracheal secretions can be used to monitor airway LT biosynthesis in patients with lung injury (57). Elevated airway LT levels may reflect airway epithelial damage but may not predict the development of adult respiratory distress syndrome (57). Recent studies also suggested an involvement of amniotic fluid surfactant in LT production (58) and demonstrated a stimulatory effect of arachidonic acid on surfactant phospholipid secretion in type II pneumocytes mediated at least in part by cysteinyl LT (59).

Cysteinyl LT appear to be important mediators of group B $\beta$-hemolytic streptococcus-induced pulmonary hypertension in newborn lambs (60). It has been shown that LT inhibition prevents and reverses hypoxic pulmonary vasoconstriction in newborn lambs (61). Therefore, specific LT synthesis inhibitors may be useful in the management of infants with persistent pulmonary hypertension. Severe bronchiolitis due to respiratory syncytial virus infection results from IgE-mediated hypersensitivity reactions to viral antigens with subsequent release 
Table 2. Elevated concentrations of leukotrienes in human diseases

\begin{tabular}{|c|c|c|c|}
\hline Disease & Source & $\mathrm{LT}^{*}$ & Ref. \\
\hline \multicolumn{4}{|l|}{ Lung diseases } \\
\hline Asthma & Sputum, urine, leukocytes & $\mathrm{LTC}_{4}, \mathrm{LTD}_{4}, \mathrm{LTE}_{4}$ & $43,49-53$ \\
\hline Cystic fibrosis & Sputum, urine, leukocytes & $\mathrm{LTB}_{4}, \mathrm{LTD}_{4}, \mathrm{LTE}_{4}$ & 54,131 \\
\hline Viral bronchiolitis & Nasopharyngeal secretion, urine & $\mathrm{LTB}_{4}, \mathrm{LTC}_{4}, \mathrm{LTD}_{4}, \mathrm{LTE}_{4}$ & 60,61 \\
\hline Adult respiratory distress syndrome & Lung edema fluid, urine & $\mathrm{LTB}_{4}, \mathrm{LTD}_{4}, \mathrm{LTE}_{4}$ & 56,132 \\
\hline $\begin{array}{l}\text { Neonatal hypoxemia with pulmonary } \\
\text { hypertension }\end{array}$ & Lung lavage fluid & $\mathrm{LTC}_{4}, \mathrm{LTD}_{4}$ & 55 \\
\hline \multicolumn{4}{|l|}{ Allergic disorders } \\
\hline Allergic rhinitis/conjunctivitis & Tears, nasal secretion, urine & $\mathrm{LTC}_{4}, \mathrm{LTD}_{4}, \mathrm{LTE}_{4}$ & 43,133 \\
\hline \multicolumn{4}{|l|}{ Connective tissue disorders } \\
\hline $\begin{array}{l}\text { (Juvenile) rheumatoid } \\
\text { arthritis/spondyloarthritis }\end{array}$ & Synovial fluid, urine & $\mathrm{LTB}_{4}, \mathrm{LTE}_{4}$ & $78-80,82$ \\
\hline Lupus erythematosus/scleroderma & Urine & $\mathrm{LTE}_{4}$ & 81 \\
\hline Gout & Synovial fluid & $\mathrm{LTB}_{4}$ & 77 \\
\hline Lyme arthritis & Synovial fluid & $\mathrm{LTB}_{4}$ & 35 \\
\hline \multicolumn{4}{|l|}{ Skin diseases } \\
\hline Psoriasis & Epidermis, urine, skin chamber fluid & $\mathrm{LTB}_{4}, \mathrm{LTC}_{4}, \mathrm{LTD}_{4}, \mathrm{LTE}_{4}$ & $95-97$ \\
\hline Urticaria & Skin chamber fluid, plasma & $\mathrm{LTE}_{4}$ & 98 \\
\hline Kawasaki disease & Leukocytes & $\mathrm{LTB}_{4}$ & 99 \\
\hline \multicolumn{4}{|l|}{ Gastrointestinal diseases } \\
\hline Inflammatory bowel disease & Mucosa, dialysate & $\mathrm{LTB}_{4}$ & $83-85,87$ \\
\hline Acute pancreatitis & Bile & $\mathrm{LTE}_{4}$ & 134 \\
\hline $\begin{array}{l}\text { Liver cirrhosis/hepatorenal } \\
\text { syndrome/hepatitis/cholestasis }\end{array}$ & Urine & $\mathrm{LTE}_{4}, \mathrm{~N}$-acetyl-LTE 4 & $44,90-92$ \\
\hline \multicolumn{4}{|l|}{ Hematogic diseases } \\
\hline Chronic myeloid leukemia & Leukocytes & $\mathrm{LTC}_{4}$ & 101 \\
\hline Sickle cell disease & Urine, plasma & $\mathrm{LTB}_{4}, \mathrm{LTC}_{4}, \mathrm{LTD}_{4}$ & 103 \\
\hline \multicolumn{4}{|l|}{ Inherited metabolic diseases } \\
\hline Peroxisome deficiency disorders & Urine & $\mathrm{LTB}_{4}, \mathrm{LTE}_{4}, \omega$-carboxy-LTE ${ }_{4} / \mathrm{LTB}_{4}$ & 34 \\
\hline Mevalonate kinase deficiency & Urine & $\mathrm{LTE}_{4}$ & 93 \\
\hline Glutathione synthetase deficiency & Urine, leukocytes & $\mathrm{LTB}_{4}, \mathrm{LTC}_{4}(\Downarrow), \mathrm{LTE}_{4}(\Downarrow)$ & 37 \\
\hline Cystinosis & Leukocytes & $\mathrm{LTC}_{4}, \mathrm{LTB}_{4}(\Downarrow)$ & 130 \\
\hline \multicolumn{4}{|l|}{ Nutritional diseases } \\
\hline Kwashiorkor & Urine, whole blood & $\mathrm{LTC}_{4}, \mathrm{LTE}_{4}, \mathrm{LTB}_{4}(\Downarrow)$ & 36 \\
\hline \multicolumn{4}{|l|}{ CNS disorders } \\
\hline Astrocytoma & Urine & $\mathrm{LTE}_{4}$ & 121 \\
\hline MS & Cerebrospinal fluid, leukocytes & $\mathrm{LTB}_{4}, \mathrm{LTC}_{4}$ & 122,123 \\
\hline \multicolumn{4}{|l|}{ Other clinical conditions } \\
\hline Myocardial ischemia & Urine & $\mathrm{LTE}_{4}$ & 42,137 \\
\hline Chronic smoking & Leukocytes & $\mathrm{LTB}_{4}$ & 138 \\
\hline Multiple trauma/severe burns & Urine, leukocytes & $\mathrm{LTE}_{4}, \mathrm{LTB}_{4}(\Downarrow)$ & $131,135,136$ \\
\hline Capillary leak syndrome & Urine & $\mathrm{LTE}_{4}$ & 94 \\
\hline Cytokine therapy & Urine & $\mathrm{LTE}_{4}, \mathrm{~N}$-acetyl-LTE & 107,108 \\
\hline
\end{tabular}

* Concentrations of the LT listed were found to be elevated unless decreased concentrations are specifically indicated by $(\Downarrow)$.

of LT leading to airway obstruction (62). The positive correlation between elevated LT levels and symptoms and the decrease in LT levels in parallel with clinical improvement after ribavirin treatment support an involvement of LT in the pathophysiology of acute viral bronchiolitis in infants (63).

Host defense. The high levels of $\mathrm{LTB}_{4}$ measured in bronchoalveolar lavages and pulmonary tissues from nonimmune animals infected with live bacteria implicate $\mathrm{LTB}_{4}$ as an important amplifier of the inflammatory response during acute pulmonary infections with mucoid Pseudomonas aeruginosa in unimmunized hosts (64). LTB $_{4}$ also exerts stimulatory effects on macrophage association and intracellular destruction, e.g. in Trypanosoma cruzi infection (65). In contrast, LT production by macrophages ingesting Toxoplasma gondii was found to be absent (69), possibly explaining the relative lack of a neutrophil inflammatory response in diseases due to obligate intracellular organisms. In general, LT formation in human leukocytes induced by various microorganisms under different conditions is probably important in host defense (66-68).

The nonimmune response to a single stimulus induces complement activation, phagocytosis, and LT generation. LT are generated by monocytes upon stimulation of their $\beta$-glucan receptor during phagocytosis (70). The release of $\mathrm{LTB}_{4}$ by monocytes during nonimmune phagocytosis is believed to potentiate recruitment and margination of leukocytes onto the interior surface of blood vessels and to create a gradient for the entry of leukocytes into the tissue space (70). In the newborn polymorphonuclear leukocytes (PMNL), chemotaxis to $\mathrm{LTB}_{4}$ in vitro is lower than in adults (71). This may protect the neonate against excessive inflammation as in bronchopulmonary dysplasia, but may also increase susceptibility to infection in the newborn.

$\omega$-Oxidation of $\mathrm{LTB}_{4}$ by PMNL is inhibited by pyocyanin, a phenazine derivative produced by $P$. aeruginosa, having im- 
portant implications for PMNL chemotaxis in vivo (72). $\omega$-Oxidation of LT was further shown to be inhibited by bifonazole (73), isoniazid (74), ethanol (75), or trifluoro-analogs of LT (76). Inhibition of $\omega$-oxidation by these substances in vivo may thus be reflected in an altered pattern of LT metabolites.

Connective tissue disorders. Elevated levels of $\mathrm{LTB}_{4}$ have been reported in synovial fluid from patients with acute flares of gout (77), spondyloarthritis (78-80), Lyme arthritis (35), and severe seropositive rheumatoid arthritis $(78-80)$, relative to patients with degenerative or traumatic joint diseases. The concentrations of $\mathrm{LTB}_{4}$ in synovial fluid in these disorders most likely contribute to the inflammatory reactions. Additionally, increased $\mathrm{LTB}_{4}$ production by stimulated PMNL has been reported from patients with rheumatoid arthritis, while elevated urinary $\mathrm{LTE}_{4}$ levels were found in patients with active systemic lupus erythematosus, scleroderma (81), and juvenile rheumatoid arthritis (82).

Gastrointestinal diseases. The concentration of $\mathrm{LTB}_{4}$ was significantly elevated in inflamed mucosal extracts from patients with inflammatory bowel disease (IBD) (83-85). It was suggested that $\mathrm{LTB}_{4} \omega$-hydroxylase activity plays an important role in the pathogenesis of IBD because the apparent $V_{\max }$ values of this enzyme in PMNL were significantly higher in patients with Crohn's disease and ulcerative colitis than in healthy control subjects (86). Furthermore, enhanced formation of cysteinyl LT was inhibited by 5 -aminosalicylic acid (84), and increased generation of $\mathrm{LTB}_{4}$ in rectal dialysis fluid from patients with ulcerative colitis could be reduced under treatment with a 5-lipoxygenase inhibitior (87). These results together with the effect of accelerated healing after application of a specific 5-lipoxygenase inhibitor in an animal model of IBD (88) should encourage further clinical trials of inhibiting LT synthesis in IBD. So far, elevated levels of cysteinyl LT have not been reported to occur in IBD. However, cysteinyl LT have been shown to mediate staphylococcal enterotoxin-induced enteric intoxication in the monkey (89).

In nonalcoholic liver cirrhosis, synthesis of $\mathrm{LTB}_{4}$ by PMNL is altered in association with an impaired $\mathrm{O}_{2}{ }^{-}$production (90). In hepatorenal syndrome, renal clearance of $\mathrm{LTE}_{4}$ is reduced, whereas excretion rate of $\mathrm{LTE}_{4}$ is increased as result of an increased production of cysteinyl LT $(44,91)$. Urinary cysteinyl LT concentrations are only slightly enhanced in patients with hepatic diseases associated with primary renal failure (44). In humans, hepatobiliary elimination of cysteinyl LT predominates over renal excretion. However, extrahepatic cholestasis leads to a compensatory diversion of cysteinyl LT elimination to the kidney with subsequent increased excretion of endogenous $\mathrm{LTE}_{4}$ into urine (92).

Capillary leak syndrome/kwashiorkor. Cysteinyl LT may induce increased vascular permeability by contracting endothelial cells $(3,7,9)$, resulting in edema and hemoconcentration. High urinary $\mathrm{LTE}_{4}$ levels were found in the edematous malnutrition syndrome kwashiorkor, suggesting that LT are involved in the pathophysiology of the syndrome, particularly in edema formation (36). During acute crisis conditions, patients with mevalonate kinase deficiency, a rare genetic defect of cholesterol biosynthesis, show features similar to those seen in capillary leak syndrome (93), a condition that is also asso- ciated with an increased urinary $\mathrm{LTE}_{4}$ excretion (94). A positive linear relationship between increased urinary excretion of mevalonate and $\mathrm{LTE}_{4}$ suggests that increased cysteinyl LT synthesis is involved in the pathogenesis of mevalonate kinase deficiency.

Skin diseases. $\mathrm{LTB}_{4}$ was found to be elevated in psoriatic skin and implicated in neutrophil infiltration leading to the formation of microabscesses in psoriasis (95). $\mathrm{LTC}_{4}$ and $\mathrm{LTD}_{4}$ obtained from skin chambers applied to lesional skin in patients with psoriasis suggest that cysteinyl LT contribute to pathology by increasing blood flow (96). Furthermore, in vivo cysteinyl LT synthesis is enhanced in psoriatic patients as measured by increased urinary $\mathrm{LTE}_{4}(97)$. The in vitro results of elevated LT levels obtained in patients with urticaria (98) and Kawasaki disease (99) still have to be confirmed by measuring their urinary $\mathrm{LTE}_{4}$ excretion as an indicator of an increased cysteinyl LT generation in vivo.

Hematologic diseases. The possible role of LT in regulating the proliferation of hemopoietic cells has been the object of several studies (100). The proliferation of both normal and malignant hemopoietic cells is stimulated by exogenous LT. However, up to now there was no evidence that hemopoesis is modulated by LT generation and that the autocrine secretion of LT is important for the continuous proliferation of leukemic cells. Abnormal formation of lipoxygenase products has been observed in chronic myeloid leukemia (101). Inasmuch as neutrophil chemotaxis to $\mathrm{LTB}_{4}$ is significantly impaired in patients with chronic granulocytic leukemia, specific defects in $\mathrm{LTB}_{4}$-mediated responses may contribute to neutrophil dysfunction in this disease (102). Results of an altered LT metabolism in sickle cell disease (103) have to be verified with additional analytical techniques. In vitro studies demonstrated an increase in eosinophil $\mathrm{LTC}_{4}$ generation in hypereosinophilic states (104). The significance of these findings with regard to the pathogenesis of hematologic disorders is still highly speculative.

Cytokines, such as IL-3 and granulocyte-macrophage colony-stimulating factor, prime cells in vitro for an enhanced biosynthesis of LT $(105,106)$ and can lead to in vivo symptoms compatible with an increased generation of LT. Clinical studies established an enhanced endogenous LT production after exogenous granulocyte-macrophage colony-stimulating factor or IL-3 treatment $(107,108)$. Furthermore, infusion studies with tumor necrosis factor lead to an increased production of cysteinyl LT in humans (109).

CNS. Human brain tissue has the capacity to synthesize large amounts of cysteinyl LT (110). LT occur in a number of regions in the normal brain, including the median eminence and other parts of the hypothalamus (111-113). Cysteinyl LT are normal constituents of the cerebrospinal fluid (114). LTC $_{4}$ is concentrated in the choroid plexus by an active transport system (113). LT are viewed as potential messengers or modulators of central nervous activity and neuroendocrine events $(110,112,115-117)$. Antibody reacting with bound $\mathrm{LTC}_{4}$ suggests that $\mathrm{LTC}_{4}$-immunoreactive nerve endings exist in mammalian brain (112). Additionally, $\mathrm{LTB}_{4}$ may contribute to neuronal dysfunction during inflammatory diseases by affecting neuronal membrane currents (118). 
LT increase blood-brain permeability and enhance the formation of vasogenic edema surrounding tumors (119). The in vitro formation of $\mathrm{LTC}_{4}$ is stimulated by intracranial tumors (120). A pathophysiologic significance of cysteinyl LT is especially suggested in human astrocytomas. Their in vivo production, as measured by urinary $\mathrm{LTE}_{4}$ excretion, correlates with the grade of malignancy and perifocal edema (121).

$\mathrm{LTB}_{4}$ and $\mathrm{LTC}_{4}$ levels in cerebrospinal fluid of patients with multiple sclerosis (MS) were significantly increased (122). Lipoxygenase products were implicated in the early encephalitic phase of MS. $\mathrm{LTB}_{4}$ and $\mathrm{LTC}_{4}$ stimulate the adherence of leukocytes in MS patients treated with high doses of prednisone, possibly reflecting alterations of membrane processes in MS leukocytes associated with calcium homeostasis and the arachidonic acid metabolic cascade (123). Finally, LT might participate in the cerebrovascular reactions in migraine (124, 125).

Renal disorders. LT have been implicated in the pathogenesis of renal disorders, including nephrotoxic serum nephritis in the rat, murine lupus nephritis, and hepatorenal syndrome in humans $(126,127)$. Studies on the normal and hydronephrotic kidney demonstrate a preferential preglomerular vasoconstriction under $\mathrm{LTD}_{4}$ and $\mathrm{LTE}_{4}$ causing a marked decrease in renal and glomerular blood flow, GFR, and filtration fraction (128). Furthermore, studies on the role of 5-lipoxygenase products in obstructive nephropathy indicated an increased synthesis of LT in the hemodynamic changes seen after unilateral release of bilateral urethral obstruction (129). It is uncertain whether plasma levels of LT are high enough to have direct effects on the kidney even under pathologic conditions (91). However, there is evidence that LT influence renal hemodynamics within the kidney inasmuch as synthesis of cysteinyl LT occurs in the kidney itself (23). It was shown that the isolated pig kidney can metabolize $\mathrm{LTE}_{4}$ by an extensive oxidative metabolism via $\beta$-oxidation from the $\omega$-end (23). The role of the kidney regarding synthesis, inactivation, and degradation of LT in man still has to be established.

Inherited metabolic diseases. The generation of $\mathrm{LTC}_{4}$ in calcium ionophore-stimulated PMNL of untreated cystinotic children was significantly increased compared with that in controls (130). $\mathrm{LTB}_{4}$ production, however, was found to be decreased. PMNL from cysteamine-treated cystinotic children generated lower amounts of $\mathrm{LTC}_{4}$ that increased after removal of cysteamine. These findings indicate an abnormal synthesis of $\mathrm{LTC}_{4}$ in PMNL in infantile cystinosis. Patients with peroxisome deficiency disorders such as the Zellweger syndrome show an impaired catabolism of LT and an altered pattern of urinary metabolites (34). Defective peroxisomal $\beta$-oxidation results in an unique pronounced urinary excretion of $\omega$-carboxy-LTE ${ }_{4}, \omega$-carboxy-LTB $\mathrm{LTB}_{4}, \mathrm{LTB}_{4}$, and massive decrease of urinary $\omega$-carboxy-tetranor- $\mathrm{LTE}_{3}$. In glutathione synthetase deficiency, an inborn error of glutathione biosynthesis leading to generalized intracellular glutathione deficiency, $\mathrm{LTC}_{4}$ synthesis is significantly decreased in ionophore-stimulated neutrophils and monocytes, whereas $\mathrm{LTB}_{4}$ synthesis is increased and other lipoxygenase products are not affected (37). Neutrophils and monocytes from those patients show a markedly reduced capacity to form $\left[{ }^{3} \mathrm{H}\right] \mathrm{LTC}_{4}$ from $\left[{ }^{3} \mathrm{H}\right] \mathrm{LTA}_{4}$. Inasmuch as urinary $\mathrm{LTE}_{4}$ is found to be greatly decreased in this disorder, glutathione synthetase deficiency may serve as a model for the linkage between LT synthesis and glutathione metabolism in vivo.

\section{PHARMACOLOGIC REGULATION OF THE GENERATION AND EFFECTS OF LT}

The current understanding of the LT biosynthetic pathway and the importance of LT in the pathogenesis of human diseases have led to the development of LT antagonists and inhibitors. Initial pharmacologic strategies for inhibition of arachidonic acid metabolism involved use of corticosteroids that were believed to inhibit LT synthesis, e.g. in IBD (83), or dietary manipulation with $\mathrm{n}-3$ fatty acids such as eicosapentenoic acid, which is highly enriched in fish oil (139-141). A preliminary study also suggests that endogenous LT production can be reduced effectively by high doses of vitamin E (142). The inhibition of 5-lipoxygenase by vitamin $\mathrm{E}$ in vivo is probably not entirely due to its antioxidant function and deserves further investigation. Today, potential strategies to block LT synthesis include inhibiting the release of arachidonic acid, preventing the conversion of arachidonic acid to $\mathrm{LTA}_{4}$ via 5-lipoxygenase enzyme inhibitors, blocking the synthesis of $\mathrm{LTB}_{4}, \mathrm{LTC}_{4}$, and $\mathrm{LTD}_{4}$, inhibiting the release of $\mathrm{LTA}_{4}$, or blocking the uptake of $\mathrm{LTA}_{4}$. In addition to inhibitors of $\mathrm{LTA}_{4}$ hydrolase, antagonists of the receptor binding of $\mathrm{LTB}_{4}$, and inhibitors of phospholipase $\mathrm{A}_{2}$, LT antagonists of clinical relevance include inhibitors of 5-lipoxygenase and $\mathrm{LTC}_{4}$ or $\mathrm{LTD}_{4}$ receptor antagonists. Several 5-lipoxygenase inhibitors are currently undergoing phase II trials. These agents either block the biologic activity of 5-lipoxygenase or its activating protein. In this group, zileuton (compound A-64077) seems promising for clinical use in the form of an oral agent (143145). Other promising agents acting as LT receptor antagonists include LY 171883 (146), ICI 204,219 (147), SK\&F 104353 (148), and MK-571 (149). Clinical trials suggest that these agents are efficacious in the management of different forms of asthma.

\section{FUTURE ASPECTS OF BIOCHEMICAL AND CLINICAL RESEARCH}

In addition to clinical and pharmacologic trials that are needed to clarify the role of LT in human disease states, future aspects of research on LT will include the development of improved analytical methods ultimately allowing quantification of $\omega$ - and $\beta$-oxidation products of $\mathrm{LTE}_{4}$ and $\mathrm{LTB}_{4}$. Further studies will concentrate on the role of the human kidney in synthesis, metabolism, and degradation of LT; the relative importance of cell compartmentation (mitochondria versus peroxisomes) to degradation and inactivation; the interaction of antioxidants (e.g. vitamin E or glutathione) and 5-lipoxygenase; and the pathophysiologic significance of LT in the CNS. Of particular interest will be the pathobiologic role of LT in the neonate, especially with respect to chronic lung disease of prematurity, sepsis, complement activation, and persistent pulmonary hypertension. 


\section{REFERENCES}

1. Murphy RC, Hammarström S, Samuelsson B 1979 Leukotriene C: a slow-reacting substance from murine mastocytoma cells. Proc Natl Acad Sci USA 76:4275-4279

2. Hammarström S 1983 Leukotrienes. Annu Rev Biochem 52:355-377

3. Samuelsson B, Dahlén SE, Lindgren JA, Rouzer CA, Serhan CN 1987 Leukotrienes and lipoxins: structures, biosynthesis, and biological effects. Science 237:1171-1176

4. Needleman P, Turk J, Jakschik BA, Morrison AR, Lefkowith JB 1986 Arachidonic acid metabolism. Annu Rev Biochem 55:69-102

5. Borgeat P, Samuelsson B 1979 Transformation of arachidonic acid by rabbit polymorphonuclear leukocytes. J Biol Chem 254:2643-2646

6. Radmark O, Malmsten C, Samuelsson B 1980 Leukotriene $\mathrm{A}_{4}$ : enzymatic conversion to leukotriene $\mathrm{C}_{4}$. Biochem Biophys Res Commun 96:1679-1687

7. Lewis RA, Austen KF 1984 The biologically active leukotrienes. Biosynthesis, metabolism, receptors, functions, and pharmacology. J Clin Invest 73:889-897

8. Verhagen J, Bruynzeel PLB, Koedam JA, Wassink GA, de Boer M, Terpstra GK, Kreukniet J, Veldink GA, Vliegenhart JFG 1984 Specific leukotriene formation by purified human eosinophils and neutrophils. FEBS Lett 168:23-28

9. Lewis RA, Austen KF, Soberman RJ 1990 Leukotrienes and other products of the 5-lipoxygenase pathway. Biochemistry and relation to pathobiology in human diseases. N Engl I Med 323:645-655

10. Odlander B, Jakobsson PJ, Rosen A, Claesson HE 1988 Human B and T lymphocytes convert leukotriene $\mathrm{A}_{4}$ into leukotriene $\mathrm{B}_{4}$. Biochem Biophys Res Commun 153:203-208

11. Dahinden CA, Wirthmueller U 1990 Release and metabolism of leukotriene $A_{4}$ in neutrophil-mast cell interactions. Methods Enzymol 187:567-577

12. Feinmark SJ 1990 Leukotriene $\mathrm{C}_{4}$ biosynthesis during polymorphonuclear leukocyte-vascular cell interactions. Methods Enzymol 187:559-567

13. Jones DA, Fitzpatrick FA 1990 Leukotriene $B_{4}$ biosynthesis by erythrocyteneutrophil interactions. Methods Enzymol 187:553-559

14. Hammarström S, Bernström K, Örning L, Dahlén SE, Hedqvist P 1981 Rapid in vivo metabolism of leukotriene $\mathrm{C}_{3}$ in the monkey, Macaca irus. Biochem Biophys Res Commun 101:1109-1115

15. Huber M, Keppler $\mathrm{D} 1987$ Inhibition of leukotriene $\mathrm{D}_{4}$ catabolism by $\mathrm{D}$ penicillamine. Eur J Biochem 167:73-79

16. Keppler D, Huber M, Baumert T, Guhlmann A 1989 Metabolic inactivation of leukotrienes. Adv Enzyme Regul 28:307-319

17. Appelgren LE, Hammarström S 1982 Distribution and metabolism of ${ }^{3} \mathrm{H}$-labeled leukotriene $\mathrm{C}_{3}$ in the mouse. J Biol Chem 257:531-535

18. Hagmann W, Denzlinger C, Keppler D 1984 Role of peptide leukotrienes and their hepatobiliary elimination in endotoxin action. Circ Shock 14:223-235

19. Keppler D, Hagmann W, Rapp S, Denzlinger C, Koch HK 1985 The relation of leukotrienes to liver injury. Hepatology 5:883-891

20. Hagmann W, Korte M 1990 Hepatic uptake and metabolic disposition of leukotriene $\mathrm{B}_{4}$ in rats. Biochem $\mathrm{J}$ 267:467-470

21. Ormstad K, Uehara N, Orrenius S, Örning L, Hammarström S 1982 Uptake and metabolism of leukotriene $\mathrm{C}_{4}$ by isolated rat organs and cells. Biochem Biophys Res Commun 104:1434-1440

22. Denzlinger C, Guhlmann A, Scheuber PJ, Wilker D, Hammer DK, Keppler D 1986 Metabolism and analysis of cysteinyl leukotrienes in the monkey. J Biol Chem 261:15601-15606

23. Moore KP, Taylor GW, Gove C, Wood J, Tan KC, Eason J, Williams R 1992 Synthesis and metabolism of cysteinyl leukotrienes by the isolated pig kidney. Kidney Int 41:1543-1548

24. Maclouf J, Antoine C, De Caterina R, Sicari R, Murphy RC, Patrignani P, Loizzo S, Patrono C 1992 Entry rate and metabolism of leukotriene $C_{4}$ into vascular compartment in healthy subjects. Am J Physiol 263:H244-H249

25. Hansson G, Lindgren JA, Dahlén SE, Hedqvist P, Samuelsson B 1981 Identification and biological activity of novel omega-oxidized metabolites of leukotriene $\mathrm{B}_{4}$ from human leukocytes. FEBS Lett 130:107-112

26. Harper TW, Garrity MJ, Murphy RC 1986 Metabolism of leukotriene $B_{4}$ in isolated rat hepatocytes. Identification of a novel 18-carboxy-19,20-dinor leukotriene $B_{4}$ metabolite. J Biol Chem 261:5414-5418

27. Shirley MA, Murphy RC 1990 Metabolism of leukotriene $B_{4}$ in isolated rat hepatocytes. Involvement of 2,4-dienoyl-coenzyme $\mathrm{A}$ reductase in leukotriene $\mathrm{B}_{4}$ metabolism. J Biol Chem 265:16288-16295

28. Leier I, Müller M, Jedlitschky G, Keppler D 1992 Leukotriene uptake by hepatocytes and hepatoma cells. Eur J Biochem 209:281-289

29. Örning L $1987 \omega$-Oxidation of cysteine-containing leukotrienes by rat liver microsomes. Isolation and characterization of $\omega$-hydroxy and $\omega$-carboxy metabolites of leukotriene $\mathrm{E}_{4}$ and $\mathrm{N}$-acetyl-leukotriene $\mathrm{E}_{4}$. Eur J Biochem 170:77-85

30. Stene DO, Murphy RC 1988 Metabolism of leukotriene $E_{4}$ in isolated rat hepatocytes. Identification of $\beta$-oxidation products of sulfidopeptide leukotrienes. J Biol Chem 263:2773-2778

31. Sala A, Voelkel N, Maclouf J, Murphy RC 1990 Leukotriene $E_{4}$ elimination and metabolism in normal human subjects. J Biol Chem 265:21771-21778

32. Huber M, Müller J, Leier I, Jedlitschky G, Ball HA, Moore KP, Taylor GW, Williams R, Keppler D 1990 Metabolism of cysteinyl leukotrienes in monkey and man. Eur J Biochem 194:309-315

33. Jedlitschky G, Huber M, Völkl A, Müller M, Leier I, Müller J, Lehmann WD, Fahimi HD, Keppler D 1991 Peroxisomal degradation of leukotrienes by $\beta$-oxidation from the $\omega$-end. J Biol Chem 266:24763-24772

34. Mayatepek E, Lehmann WD, Fauler J, Tsikas D, Frölich JC, Schutgens RBH, Wanders RJA, Keppler D 1993 Impaired degradation of leukotrienes in patients with peroxisome deficiency disorders. J Clin Invest 91:881-888
35. Mayatepek E, Hassler D, Maiwald M 1993 Enhanced levels of $\mathrm{LTB}_{4}$ in synovial fluid in Lyme disease. Mediat Inflamm 3:225-228

36. Mayatepek E, Becker K, Gana L, Hoffmann GF, Leichsenring M 1993 Leuoktrienes in the pathophysiology of kwashiorkor. Lancet 342:958-960

37. Mayatepek E, Hoffmann GF, Carlsson B, Larsson A, Becker K 1994 Impaired synthesis of lipoxygenase products in glutathione synthetase deficiency. Pediatr Res 35:305-310

38. Maltby NH, Taylor GW, Ritter JM, Moore K, Fuller RW, Dollery CT 1990 Leukotriene $\mathrm{C}_{4}$ elimination and metabolism in man. J Allergy Clin Immunol 85:3-9

39. Örning L, Kaijser L, Hammarström S 1985 In vivo metabolism of leukotriene $\mathrm{C}_{4}$ in man: urinary excretion of leukotriene $\mathrm{E}_{4}$. Biochem Biophys Res Commun 130:214220

40. Serafin WE, Oates JA, Hubbard WC 1984 Metabolism of leukotriene $B_{4}$ in the monkey. Identification of the principal nonvolatile metabolite in the urine. Prostaglandins 27:899--911

41. Keppler D, Huber M, Hagmann W, Ball HA, Guhlmann A, Kästner S 1988 Metabolism and analysis of endogenous cysteinyl leukotrienes. Ann NY Acad Sci 524:68-74

42. Tagari P, Ethier D, Carry M, Korley V, Charleson S, Girard Y, Zamboni R 1989 Measurement of urinary leukotrienes by reversed-phase liquid chromatography and radioimmunoassay. Clin Chem 35:388-391

43. Taylor GW, Taylor I, Black P, Maltby NH, Turner N, Fuller RW, Dollery CT 1989 Urinary leukotriene $\mathrm{E}_{4}$ after antigen challenge in acute asthma and allergic rhinitis. Lancet 1:584-588

44. Huber M, Kästner S, Schölmerich J, Gerok W, Keppler D 1989 Analysis of cysteinyl leukotrienes in human urine: enhanced excretion in patients with liver cirrhosis and hepatorenal syndrome. Eur J Clin Invest 19:53-60

45. Borgeat P, Picard S, Vallerand P, Bourgoin S, Odeimat A, Siros P, Poubelle PE 1990 Automated on-line extraction and profiling of lipoxygenase products of arachidonic acid by high-performance liquid chromatography. Methods Enzymol 187:98-116

46. Murphy RC 1984 Mass spectrometric quantitation and analysis of leukotrienes and other 5-lipoxygenase metabolites. Prostaglandins 28:597-601

47. Mathews R 1990 Quantitative gas chromatography-mass spectrometry analysis of leukotriene $\mathrm{B}_{4}$. Methods Enzymol 187:76-81

48. Murphy RC, Sala A 1990 Quantitation of sulfidopeptide leukotrienes in biological fluids by gas chromatography-mass spectrometry. Methods Enzymol 187:90-98

49. Dahlén S, Hansson G, Hedqvist P, Björk T, Granström E, Dahlén B 1983 Allergen challenge of lung tissues from asthmatics elicits bronchial contraction that correlates with the release of leukotrienes $\mathrm{C}_{4}, \mathrm{D}_{4}$, and $\mathrm{E}_{4}$. Proc Natl Acad Sci USA 80:17121716

50. Lam S, Chan H, LeRiche JC, Chan-Yeung M, Salari H 1988 Release of leukotrienes in patients with bronchial asthma. J Allergy Clin Immunol 81:711-717

51. Wardlaw AJ, Hay H, Cromwell O, Collins JV, Kay AB 1989 Leukotrienes, LTC and $\mathrm{LTB}_{4}$, in bronchoalveolar lavage in bronchial asthma and other respiratory diseases. J Allergy Clin Immunol 84:19-26

52. Ferreri NR, Howland WC, Stevenson DD, Spielberg HL 1988 Release of leukotrienes, prostaglandins, and histamine into nasal secretions of aspirin-sensitive asthmatics during reaction to aspirin. Am Rev Respir Dis 137:847-854

53. Kikawa Y, Hosoi S, Inoue Y, Saito M, Nakai A, Shigematsu Y, Hirao T, Sudo M 1991 Exercise-induced urinary excretion of leukotriene $E_{4}$ in children with atopic asthma. Pediatr Res 29:455-459

54. Cromwell O, Walport MJ, Morris H, Taylor GW, Hodson ME, Batten J, Kay AB 1981 Identification of leukotrienes D and B in sputum from cystic fibrosis patients. Lancet 8239:164-165

55. Stenmark KR, James SL, Voelkel NF, Toews WH, Reeves JT, Murphy RC 1983 Leukotrienes $\mathrm{C}_{4}$ and $\mathrm{D}_{4}$ in neonates with hypoxemia and pulmonary hypertension. N Engl J Med 309:77-80

56. Matthay MA, Eschenbacher WL, Goetzl EJ 1984 Elevated concentrations of leukotriene $\mathrm{D}_{4}$ in pulmonary edema fluid of patients with adult respiratory distress syndrome. J Clin Immunol 4:479-483

57. Sala A, Murphy RC, Voelkel NF 1991 Direct airway injury results in elevated levels of sulfidopeptide leukotrienes, detectable in airway secretions. Prostaglandins 42:1-7

58. Lee HC, Ikenoue T, Miyakawa I, Mori N 1992 Amniotic fluid embolism and leukotrienes-the role of amniotic fluid surfactant in leukotriene production. Prostaglandins Leukot Essent Fatty Acids 47:117-121

59. Gilfillan AM, Rooney SA 1986 Leukotrienes stimulate phosphatidylcholine secretion in cultured type II pneumocytes. Biochim Biophys Acta 876:22-27

60. Schreiber MD, Covert RF, Torgerson LJ 1992 Hemodynamic effects of heat-killed group $B \quad \beta$-hemolytic streptococcus in newborn lambs: role of leukotriene $D_{4}$ Pediatr Res 31:121-126

61. Schreiber MD, Heymann MA, Soifer SJ 1985 Leukotriene inhibition prevents and reverses hypoxic pulmonary vasoconstriction in newborn lambs. Pediatr Res 19:437-441

62. Volovitz B, Welliver RC, De Castro G, Krystofik DA, Ogra PL 1988 The release of leukotrienes in the respiratory tract during infection with respiratory syncytial virus: role in obstructive airway disease. Pediatr Res 24:504-507

63. Cook AJ, Sampson AP, Green CP, Spencer DA, Piper PJ, Price JF 1992 Leukotrienes in infants with acute viral bronchiolitis. Br J Clin Pharmacol 34:1992(abstr)

64. Buret A, Dunkley M, Clancy RL, Cripps AW 1993 Effector mechanisms of intestinally induced immunity to Pseudomonas aeruginosa in the rat lung: role of neutrophils and leukotriene $\mathrm{B}_{4}$. Infect Immun 61:671-679 
65. Wirth JJ, Kierszenbaum F 1985 Stimulatory effects of leukotriene $B_{4}$ on macrophage association with and intracellular destruction of Trypanosoma cruzi. J Immunol 134:1989-1993

66. Claesson HE, Lindgren JA, Gustafsson B 1985 Opsonized bacteria stimulate leukotriene synthesis in human leukocytes. Biochim Biophys Acta 836:361-367

67. König W, Scheffer J, Bremm KD, Hacker J, Goebel W 1985 Role of bacterial adherence and toxin production from Escherichia coli on leukotriene generation from human polymorphonuclear granulocytes. Int Arch Allergy Appl Immun 77:118-120

68. Pang T, Devi S, Puthucheary S, Pawlowski N 1991 Heat-killed Salmonella typhi induces the release of prostaglandins and leukotrienes from mouse macrophages. Microbiol Immunol 35:267-271

69. Locksley RM, Fankhauser J, Henderson WR 1985 Alteration of leukotriene release by macrophages ingesting Toxoplasma gondii. Proc Natl Acad Sci USA 82:69226926

70. Czop JK, Austen KF 1985 Generation of leukotrienes by human monocytes upon stimulation of their $\beta$-glucan receptor during phagocytosis. Proc Natl Acad Sci USA 82:2751-2755

71. Dos Santos C, Davidson D 1993 Neutrophil chemotaxis to leukotriene $B_{4}$ in vitro is decreased for the human neonate. Pediatr Res 33:242-246

72. Muller M, Sorrell TC 1992 Leukotriene $\mathrm{B}_{4} \omega$-oxidation by human polymorphonuclear leukocytes is inhibited by pyocyanin, a phenazine derivative produced by Pseudomonas aeruginosa. Infect Immun 60:2536-2540

73. Bremm KD, Plempel M 1991 Modulation of leukotriene metabolism from human polymorphonuclear granulocytes by bifonazole. Mycoses 34:41-45

74. Parthé S, Hagmann W 1990 Inhibition of leukotriene $\omega$-oxidation by isonicotinic acid hydrazide (isoniazid). Eur J Biochem 187:119-124

75. Baumert T, Huber M, Mayer D, Keppler D 1989 Ethanol-induced inhibition of leukotriene degradation by $\omega$-oxidation. Eur J Biochem 182:223-229

76. Jedlitschky G, Leier I, Huber M, Mayer D, Keppler D 1990 Inhibition of leukotriene $\omega$-oxidation by $\omega$-triffuoro analogs of leukotrienes. Arch Biochem Biophys 282:333-339

77. Rae SA, Davidson EM, Smith MJH 1982 Leukotriene $B_{4}$, an inflammatory mediator in gout. Lancet 2:1122-1124

78. Belch JJ, O'Dowd A, Ansell D, Sturrock RD 1989 Leukotriene B $_{4}$ production by peripheral blood neutrophils in rheumatoid arthritis. Scand J Rheumatol 18:13-19

79. Klickstein LB, Shapleigh C, Goetzl EJ 1980 Lipoxygenation of arachidonic acid as a source of polymorphonuclear leukocyte chemotactic factors in synovial fluid an tissue in rheumatoid arthritis and spondyloarthritis. J Clin Invest 66:1166-1170

80. Davidson EM, Rae SA, Smith MJ 1983 Leukotriene $\mathrm{B}_{4}$, a mediator of inflammation present in synovial fluid in rheumatoid arthritis. Ann Rheum Dis 43:677-679

81. Hackshaw KV, Voelkel NF, Thomas RB, Westcott JY 1992 Urine leukotriene $\mathrm{E}_{4}$ levels are elevated in patients with active systemic lupus erythematosus. J Rheumatol 19:252-258

82. Fauler J, Thon A, Tsikas D, von der Hardt H, Frölich JC 1994 Enhanced synthesi of cysteinyl leukotrienes in juvenile rheumatoid arthritis. Arthritis Rheum 37:93-97

83. Sharon P, Stenson WF 1984 Enhanced synthesis of leukotriene $B_{4}$ by colonic mucosa in inflammatory bowel disease. Gastroenterology 86:453-460

84. Peskar BM, Dreyling KW, Peskar BA, May B, Goebell H 1986 Enhanced formation of sulfidopeptide-leukotrienes in uicerative colitis and Crohn's disease: inhibition by sulfasalazine and 5-aminosalicylic acid. Agents Actions 18:381-383

85. Lauritsen K, Laursen LS, Bukhave K, Rask-Madsen J 1986 Effects of topical 5 -aminosalicylic acid and prednisolone on prostaglandin $E_{2}$ and leukotriene $B_{4}$ levels determined by equilibrium in vivo dialysis of rectum in relapsing ulcerative colitis. Gastroenterology 91:837-844

86. Ikehata A, Hiwatashi N, Kinouchi Y, Ito K, Yamazaki H, Toyota T 1993 Leukotriene $\mathrm{B}_{4} \omega$-hydroxylase activity in polymorphonuclear leukocytes from patients with inflammatory bowel disease. Prostaglandins Leukot Essent Fatty Acids 49:489-494

87. Laursen LS, Naesdal J, Bukhave K, Lauritsen K, Rask-Madsen J 1990 Selective 5-lipoxygenase inhibition in ulcerative colitis. Lancet 335:683-685

88. Wallace JL, MacNaughton WK, Morris GP, Beck PL 1989 Inhibition of leukotriene synthesis markedly accelerates healing in a rat model of inflammatory bowe disease. Gastroenterology 96:29-36

89. Scheuber PH, Denzlinger C, Wilker D, Beck G, Keppler D, Hammer DK 1987 Cysteinyl leukotrienes as mediators of staphylococcal enterotoxin $\mathrm{B}$ in the monkey. Eur $J$ Clin Invest 17:455-459

90. Laffi G, Carloni V, Baldi E, Rossi ME, Azzari C, Gresele P, Marra F, Gentilini P 1993 Impaired superoxide anion, platelet-activating factor, and leukotriene $\mathrm{B}_{4}$ synthesis by neutrophils in cirrhosis. Gastroenterology 105:170-177

91. Moore KP, Taylor GW, Maltby NH, Siegers D, Fuller RW, Dollery CT, William R 1990 Increased production of cysteinyl leukotrienes in hepatorenal syndrome. Hepatol 11:263-271

92. Mayatepek E, Pecher G 1993 Increased excretion of endogenous urinary leukotriene $E_{4}$ in extrahepatic cholestasis. Clin Chim Acta 218:185-192

93. Mayatepek E, Hoffmann GF, Bremer HJ 1993 Enhanced urinary excretion of leukotriene $E_{4}$ in patients with mevalonate kinase deficiency. J Pediatr 123:96-98

94. Cahill RA, Zhao Y, Murphy R, Sala A, Foegh M, Spitzer T, Deeg HJ 1990 High urinary leukotriene $\mathrm{E}_{4}$ and thromboxane $\mathrm{B}_{2}$ levels are associated with capillary leak syndrome in bone marrow transplant patients. Adv Prostaglandin Thromboxane Leukot Res 21:525-528

95. Brain SD, Camp RDR, Derm FF, Dowd PM, Kobza Black A, Greaves MW 1984 The release of leukotriene $B_{4}$-like material in biologically active amounts from lesional skin of patients with psoriasis. J Invest Dermatol 83:70-73

96. Brain SD, Camp RDR, Kobza Black A, Dowd PM, Greaves MW, Ford-Hutchinson $\mathrm{AW}$, Charleson $\mathrm{S} 1985$ Leukotrienes $\mathrm{C}_{4}$ and $\mathrm{D}_{4}$ in psoriatic skin lesions. Prostaglandins 29:611-619
97. Fauler J, Neumann C, Tsikas D, Frölich J 1992 Enhanced synthesis of cysteinyl leukotrienes in psoriasis. J Invest Dermatol 99:8-11

98. Maltby NH, Ind PW, Causon RC, Fuller RW, Taylor GW 1989 Leukotriene $\mathrm{E}_{4}$ release in cold urticaria. Clin Exp Allergy 19:33-36

99. Hamasaki Y, Ichimaru T, Koga H, Tasaki H, Miyazaki S 1989 Increased in vitro leukotriene $\mathrm{B}_{4}$ production by stimulated polymorphonuclear cells in Kawasaki disease. Acta Paediatr Jpn 31:346-348

100. Wickremasinghe RG, Khan MA, Hoffbrand AV 1993 Do leukotrienes play a role in the regulation of proliferation of normal and leukemic hemopoetic cells? Prostaglandins Leukot Essent Fatty Acids 48:123-126

101. Stenke L, Näsman-Glaser B, Edenius C, Samuelsson J, Palmblad J, Lindgren A 1990 Lipoxygenase products in myeloproliferative disorders: increased leukotriene $\mathrm{C}_{4}$ and decreased lipoxin formation in chronic myeloid leukemia. Adv Prostaglandin Thromboxane Leukot Res 21:883-886

102. Reilly IAG, Knapp HR, Fitzgerald GA 1988 Leukotriene $B_{4}$ synthesis and neutrophil chemotaxis in chronic granulocytic leukaemia. J Clin Pathol 41:1163-1167

103. Ibe BO, Kurantsin-Mills J, Usha Raj J, Lessin LS 1994 Plasma and urinary leukotrienes in sickle cell disease: possible role in the inflammatory process. Eur J Clin Invest 24:57-64

104. Sheff DM, Owen Jr WF, Austen KF 1990 Eosinophil phenotypes and $\mathrm{LTC}_{4}$ generation in vitro and in hypereosinophilic states. Adv Prostaglandin Thromboxane Leukot Res 21:481-488

105. Kurimoto Y, de Weck AL, Dahinden CA 1989 Interleukin 3-dependent mediator release in basophils triggered by C5a. J Exp Med 170:467-479

106. McColl SR, Krump E, Naccache PH, Borgeat P 1989 Enhancement of human neutrophil leukotriene synthesis by human granulocyte-macrophage colonystimulating factor. Agents Actions 27:465-468

107. Denzlinger C, Kapp A, Grimberg M, Gerhartz HH, Wilmanns W 1990 Enhanced endogenous leukotriene biosynthesis in patients treated with granulocytemacrophage colony-stimulating factor. Blood 76:1765-1770

108. Denzlinger C, Walther J, Wilmanns W, Gerhartz HH 1993 Interleukin-3 enhances the endogenous leukotriene production. [letter] Blood 81:1975-1976

109. Moore KP, Sheron N, Ward P, Taylor GW, Alexander GJM, Williams R 1991 Leukotriene and prostaglandin production after infusion of tumor necrosis factor in man. Eicosanoids 4:115-118

110. Simmet T, Luck W, Delank WK, Peskar BA 1988 Formation of cysteinylleukotrienes by human brain tissue. Brain Res 456:344-349

111. Lindgren JA, Hökfelt T, Dahlén SE, Patrono C, Samuelsson B 1984 Leukotrienes in the rat central nervous system. Proc Natl Acad Sci USA 81:6212-6216

112. Hulting AL, Lindgren LA, Hökfelt T, Eneroth $\mathrm{P}$, Werner S, Patrono C, Samuelsson B 1985 Leukotriene $\mathrm{C}_{4}$ as a mediator of luteinizing hormone release from rat anterior pituitary cells. Proc Natl Acad Sci USA 82:3834-3838

113. Spector R, Goetzl EJ 1986 Role of concentrative leukotriene transport systems in the central nervous system. Biochem Pharmacol 35:2849-2853

114. Hynes N, Bishai I, Lees J, Coceani F 1991 Leukotrienes in brain: natural occurrence and induced changes. Brain Res 553:4-13

115. Palmer MR, Mathews R, Murphy RC, Hoffer BJ 1980 Leukotriene C elicits a prolonged excitation of cerebellar Purkinje neurons. Neurosci Lett 18:173-180

116. Palmer MR, Mathews R, Hoffer BJ, Murphy RC 1981 Electrophysiological response of cerebellar Purkinje neurons to leukotriene $\mathrm{D}_{4}$ and $\mathrm{B}_{4}$. J Pharmacol Exp Ther 219:91-96

117. Gerozissis K, Rougeot C, Dray F 1986 Leukotriene $\mathrm{C}_{4}$ is a potent stimulator of LHRH secretion. Eur J Pharmacol 121:159-160

118. Köller H, Siebler M 1993 Impaired neuronal function induced by the immune modulator leukotriene $\mathrm{B}_{4}$. Brain Res 628:313-316

119. Black KL, Hoff JT 1985 Leukotrienes increase blood-brain barrier permeability following intraparenchymal injections in rats. Ann Neurol 18:349-351

120. Black KL, Hoff JT, McGillicuddy JE, Gebarski SS 1986 Increased leukotriene $C_{4}$ and vasogenic edema surrounding brain tumors in humans. Ann Neurol 19:592-595

121. Winking M, Lausberg G, Simmet T 1991 Cysteinyl-leukotriene production by human astrocytomas in vivo correlates with the malignancy grade and the perifocal edema. Eicosanoids 4(suppl):S28(abstr)

122. Neu I, Mallinger J, Prosiegel M, Wildfeuer A, Mehlber L, Ruhenstroth-Bauer G 1988 Multiple Sklerose: Leukotriene im Liquor cerebrospinalis. Münch Med Wochenschr 130:80-81

123. Mayer M 1988 Effect of calcium ionophore $A 23187$ and of leukotriene $B_{4}$ and $C_{4}$ on the adherence of mononuclear leucocytes in multiple sclerosis. Folia Biol 34:10-17

124. Parantainen J, Vapaatalo H, Hokkanen E 1986 Clinical aspects of prostaglandins and leukotrienes in migraine. Cephalagia 6(suppl 4):95-101

125. Puig-Parellada P, Planas JM, Gimenez J, Obach J 1993 Migraine: implications of arachidonic acid metabolites. Prostaglandins Leukot Essent Fatty Acids 49:537-547

126. Badr KF, Schreiner GF, Wasserman M, Ichikawa I 1988 Preservation of the glomerular capillary ultrafiltration coefficient during rat nephrotoxic serum nephritis by a specific leukotriene $D_{4}$ receptor antagonist. J Clin Invest 81:1702-1709

127. Spurney RF, Ruiz P, Pisetsky DS, Coffman TM 1991 Enhanced renal leukotriene production in murine lupus: role of lipoxygenase metabolites. Kidney Int 39:95-102

128. Gulbins E, Parekh N, Rauterberg EW, Schlottmann K, Steinhausen M 1991 Cysteinyl leukotriene actions on the microcirculation of the normal and split hydronephrotic rat kidney. Eur J Clin Invest 21:184-196

129. Reyes AA, Lefkowith J, Pippin J, Klahr S 1992 Role of the 5-lipoygenase pathway in obstructive nephropathy. Kidney Int 41:100-106

130. Pintos-Morell G, Salem P, Jean G, Niaudet P, Mencia-Huerta JM 1994 Altered leukotriene generation in leukocytes from cystinotic children. Pediatr Res 36:628634 
131. Piper PJ, Conroy DM, Costello JF, Evans JM, Green CP, Price JF, Sampson AP, Spencer DA 1991 Leukotrienes and inflammatory lung diseases. Ann NY Acad Sci 629:112-119

132. Westcott JY, Thomas RB, Voelkel NF 1991 Elevated urinary leukotriene $E_{4}$ excretion in patients with ARDS and severe burns. Prostaglandins Leukot Essent Fatty Acids 43:151-158

133. Bisgaard H, Ford-Hutchinson AW, Charleson S, Taudorf E 1985 Production of leukotrienes in human skin and conjunctival mucosa after specific allergen challenge. Allergy 40:417-423

134. Keppler D, Huber M, Weckbecker G, Hagmann W, Denzlinger C, Guhlmann A 1987 Leukotriene $\mathrm{C}_{4}$ metabolism by hepatoma cells and liver. Adv Enzyme Regu 26:211-224

135. Fauler J, Tsikas D, Holch M, Seekamp A, Nerlich ML, Sturm J, Frölich JC 1991 Enhanced urinary excretion of leukotriene $\mathrm{E}_{4}$ by patients with multiple trauma with or without adult respiratory distress syndrome. Clin Sci 80:497-504

136. König W, Schönfeld W, Raulf M, Köller M, Knöller J, Scheffer J, Brom J 1990 The neutrophil and leukotrienes: role in health and disease. Eicosanoids 3:1-22

137. Carry M, Korley V, Willerson JT, Weigelt L, Ford-Hutchinson AW, Tagari P 1992 Increased urinary leukotriene excretion in patients with cardiac ischemia. Circulation 85:230-236

138. Schlosser K, Ulmer WT 1988 Increased leukotriene $B_{4}$ synthesis in polymorphonuclear leukocytes of smokers. Klin Wochenschr 66(suppl XI):120-124

139. DeGeorge JJ, Ousley AH, McCarthy KD, Morell P, Lapetina EG 1987 Glucocorticoids inhibit the liberation of arachidonate but not the rapid production of phospholipase-C dependent metabolites in acetylcholine-stimulated $\mathrm{C} 62 \mathrm{~B}$ glioma cells. J Biol Chem 262:9979-9983

140. Lee TH, Hoover RL, Williams JD, Sperling RI, Ravalese J III, Spur BW, Robinson DR, Corey EJ, Lewis RA, Austen KF 1985 Effect of dietary enrichment with eicosapentenoic and docosahexanoic acids on in vitro neutrophil and monocyte leukotriene generation and neutrophil function. N Engl J Med 312:1217-1224
141. Mayatepek E, Paul K, Leichsenring M, Pfisterer M, Wagner D, Domann M, Sonntag HG Bremer HJ 1994 Influence of dietary (n-3)-polyunsaturated fatty acids on leukotriene $B_{4}$ and prostaglandin $E_{2}$ synthesis and course of experimental tuberculosis in guinea pigs. Infection 22:106-112

142. Denzlinger C, Sagebiel S, Haber C, Kless T, Jacob K, Adam O, Wilmanns W 1993 Modulation of the endogenous leukotriene production by vitamin $\mathrm{E}$ and fish oil. 3rd International Conference on Lipid Mediators in Health \& Disease, Jerusalem, Israel, October 31-November 4, 1993, p PI-4(abstr)

143. Bell RL, Young PR, Albert D, Lanni C, Summers JB, Brooks DW, Rubin P, Carter GW 1992 The discovery and development of zileuton: an orally active 5-lipoxygenase inhibitor. Int $\mathrm{J}$ Immunopharmacol 14:505-510

144. Israel E, Demarkarian R, Rosenberg M, Sperling R, Taylor G, Rubin P, Drazen JM 1990 The effects of a 5-lipoxygenase inhibitor on asthma induced by cold air. N Engl J Med 323:1740-1744

145. Knapp HR 1990 Reduced allergen-induced nasal congestion and leukotriene synthesis with orally active 5-lipoxygenase inhibitor. N Engl J Med 323:1745-1748

146. Fleisch JH, Rinkema LE, Haisch KD 1985 LY 17883, 1-<2-hydroxy-3-propyl-4$<-\left(1 \mathrm{H}\right.$-tetrazol-5-yl)butoxy $>$ phenyl $>$ ethanone, an orally active leukotriene $\mathrm{D}_{4}$ antagonist. J Pharmacol Exp Ther 233:148-157

147. Finnerty JP, Wood-Baker R, Thomson H, Holgate ST 1992 Role of leukotrienes in exercise-induced asthma. Inhibitory effect of ICI 204,219, a potent leukotriene $\mathrm{D}_{4}$ receptor antagonist. Am Rev Respir Dis 145:746-749

148. Robuschi M, Riva E, Fuccella LM, Vida E, Barnabe R, Rossi M, Gambaro G, Spagnotto S, Bianco S 1992 Prevention of exercise induced bronchoconstriction by a new leukotriene antagonist (SK\&F 104353). A double-blind study versus disodium cromoglycate and placebo. Am Rev Respir Dis 145:1285-1288

149. Manning PJ, Watson RM, Margolskee DJ, Williams VC, Schwartz JI, O'Byrne PM 1990 Inhibition of exercise-induced bronchoconstriction by MK-571, a potent leukotriene $\mathrm{D}_{4}$-receptor antagonist. $\mathrm{N}$ Engl J Med 323:1736-1739 